\title{
DIFUSI KEBIJAKAN KETERBUKAAN INFORMASI PUBLIK DI KABUPATEN BANDUNG BARAT
}

\author{
Rochmat Bahtiar, Mohammad Benny Alexandri, Candradewini \\ Program Pasca Sarjana Kebijakan Publik \\ Fakultas Ilmu Sosial dan Ilmu Politik \\ Universitas Padjadjaran \\ aambahtiar@gmail.com,mohammad.benny@unpad.ac.id, candradewini@unpad.ac.id
}

\begin{abstract}
ABSTRAK
Penelitian ini dilakukan untuk mengetahui bagaimana Pemerintah Kabupaten Bandung Barat menerapkan kebijakan Keterbukaan Informasi Publik melalui mekanisme difusi kebijakan. Empat mekanisme utama difusi kebijakan yaitu, pembelajaran, persaingan, peniruan dan pemaksaan yang telah dilakukan oleh Pemerintah Kabupaten Bandung Barat akan dipaparkan melalui metode penelitian kualitatif deskriptif. Dengan begitu dapat secara eksplisit dapat terlihat berbagai upaya yang dilakukan dalam menentukan pilihan kebijakan yang dipengaruhi oleh penerapan kebijakan serupa yang dilakukan oleh Pemerintah Daerah lain.

Kata kunci : Kebijakan Publik, Difusi Kebijakan, Keterbukaan Informasi Publik
\end{abstract}

\begin{abstract}
The study was conducted to see how the Government of Bandung Barat District implemented the Public Information Disclosure policy through policy diffusion mechanism. The four main mechanism of policy diffusion, namely, learning, competition, imitation and coercion that have been carried out by the Government of Bandung Barat District will be presented through descriptive qualitative research methods. In this way, it can be seen explicitly from the various policies made in determining policy choices that can be based on policies taken by other local governments.

Keywords: Public Policy, Policy Diffusion, Public Information Disclosure
\end{abstract}

\section{PENDAHULUAN}

Penelitian ini dilakukan dalam rangka menganalisis difusi kebijakan Keterbukaan Informasi Publik (KIP) di Kabupaten Bandung Barat (KBB). Analisis dilakukan dengan cara memaparkan cara yang dilakukan oleh Pemerintah Daerah Kabupaten Bandung Barat dalam menerapkan kebijakan KIP sejak diberlakukannya Undang-Undang Keterbukaan Informasi Publik No. 14 Tahun 2008 (UU-KIP, 2008).

Penelitian terdahulu mengenai difusi kebijakan dilakukan dengan tema yang berbeda seperti, "Proses Difusi Inovasi E-Agribusiness : Regopantes Pada End-User Komoditas Pertanian Di Jabodetabek” (Meydora, 2019), yang menganalisis proses penyebaran inovasi eagribisnis untuk menghubungkan petani dengan pengguna komoditas pertanian secara langsung. Kemudian, "Difusi Kebijakan Upaya Fundamental Kebijakan Pemerintah Daerah" (Andhika, 2018), yang menjelaskan mekanisme, dan masalah difusi kebijakan untuk menghasilkan kebijakan pemerintah daerah. Lalu "Difusi Inovasi Dalam Meningkatkan Partisipasi Masyarakat Akan Kelestarian Lingkungan” (Ahmad, 2016), yang menjelaskan model konseptual yang sedang disebarkan oleh komunitas kepada masyarakat RW 13 Tamansari yaitu berupa gagasan gerakan Cikapundung bersih. Untuk mengkomunikasikan gagasan ini komunitas menggunakan dua saluran komunikasi (intrapersonal dan media massa). Serta "Difusi Kebijakan Pengarusutamaan Gender Pada Individu: Refleksi Terhadap Metode Penelitian Difusi” (Hajaroh, 2013), yang menjelaskan model konseptual difusi kebijakan, faktor-faktor penentu adopsi, dan metode penelitian difusi pengarusutamaan gender (PUG).

Lokus penelitian ditentukan dengan teknik klaster atas tingkat pelayanan informasi publik yang dilaksanakan oleh badan publik, mengacu pada Symmons dan Cress-man (2001) 
dalam (J. Zhang \& College, 2017) dengan mengelompokkan kandidat dari lokus penelitian. Peneliti membuat kategori badan publik Pemerintah Daerah berdasarkan kedekatan geografis yaitu 'Pemerintah Daerah se-Bandung Raya' yang terdiri dari : 1)Pemerintah Kota Bandung, 2)Pemerintah Kota Cimahi, 3)Pemerintah Kabupaten Bandung dan 4)Pemerintah Kabupaten Bandung Barat. Yang dilanjutkan dengan pemeringkatan kualitas penyelenggaraan kebijakan KIP pemerintahan daerah. dengan nilai dalam persentase sebagai berikut:

Tabel 1.1

Pemeringkatan Ketersediaan Informasi Publik Se- Bandung Raya

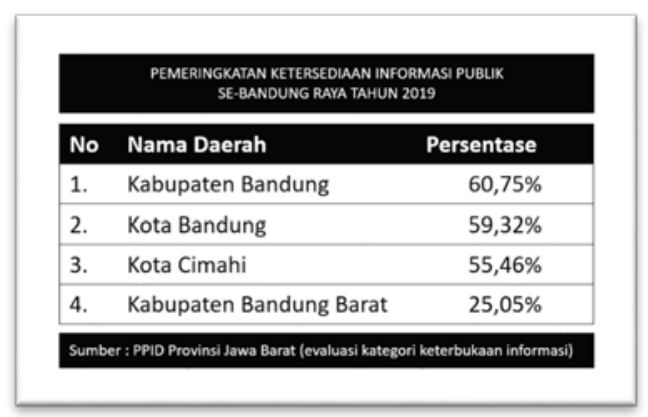

Data dari hasil penilaian self assessment questionnaire monitoring dan evaluasi kategori Keterbukaan Informasi Pemerintah Daerah oleh PPID Provinsi Jawa Barat pada tahun 2019, menunjukkan hasil bahwa PPID Kabupaten Bandung Barat masih berada di bawah 50\% (lima puluh persen). Dari hasil pemeringkatan tersebut, maka peneliti memutuskan memilih lokus di Pemerintah Kabupaten Bandung Barat (KBB) untuk dapat diteliti secara lebih mendalam sehingga bisa mendapatkan penjelasan mengenai fenomena yang terjadi.

Dari penelusuran awal penelitian, didapatkan data yang hasil wawancara dan observasi berupa : 1). keterangan bahwa Bagian Prokopim tidak menyelenggarakan Pengelolaan Pelayanan Informasi dan Dokumentasi, karena pada (Kepbup-PPID, 2017) Bagian Prokopim tidak ditugaskan atau ditetapkan sebagai bagian dari PPID Kabupaten Bandung Barat dan tidak mengetahui instansi mana yang saat ini berwenang sebagai PPID; 2). keterangan dari mantan Pejabat PPID Utama Kabupaten Bandung Barat, bahwa Pengelolaan Pelayanan Informasi dan Dokumentasi KBB pada tahun 2018 telah dijalankan, meskipun tidak memiliki dukungan yang cukup. Namun Pengelolaan
Pelayanan Informasi dan Dokumentasi telah diselenggarakan secara langsung ataupun melalui Aplikasi Penunjang PPID Online. 3.) hasil observasi pada penyelenggaraan Pelayanan Informasi dan Dokumentasi KBB melalui situs: https://www.ppid.bandungbaratkab.go.id.

dengan data-data yaitu, keberadaan dan fungsi aplikasi yang masih aktif, dan bisa diakses, ditampilkan secara utuh beberapa menu dan fitur penunjangnya, berbagai informasi kegiatan pemerintah terpampang pada halaman awal situs yang diurutkan berdasar tanggal pelaksanaan kegiatannya, yang tersaji sebagai berikut:

Gambar 1.1

Aplikasi penunjang PPID online Kabupaten Bandung Barat

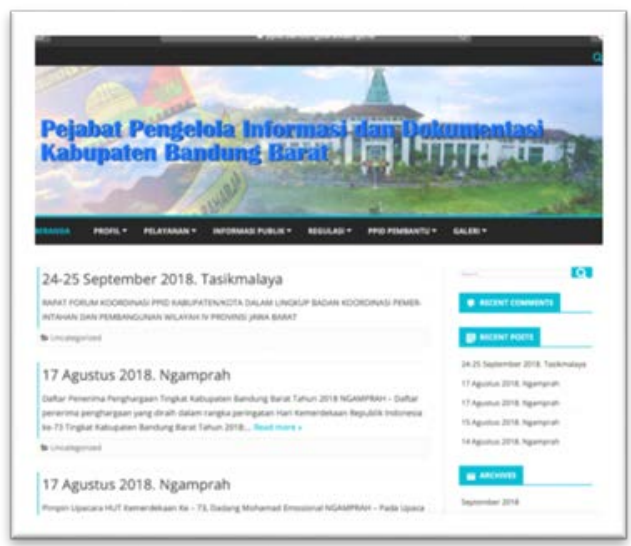

Sumber : Data diolah Peneliti (2020)

Dari pendalaman yang dilakukan, peneliti mendapatkan data bahwa aplikasi PPID online Kabupaten Bandung Barat sudah usang, terlihat dari unggahan terakhir pada tanggal 25 September 2018, beberapa pilihan menu tidak bisa berfungsi, dan tidak tersedianya informasi dan dokumentasi publik sebagaimana diamanatkan dalam (Perbup-PPID, 2018; UUKIP, 2008) bahwa informasi publik merupakan informasi yang dihasilkan, disimpan, dikelola, dikirim atau diterima, yang berkaitan dengan penyelenggaraan pemerintahan, dengan kriteria: 1).informasi yang secara berkala wajib disediakan dan diumumkan; 2).informasi yang secara serta merta wajib diumumkan; 3).informasi yang wajib tersedia setiap saat; dan 4).informasi-informasi dalam kategori dikecualikan.

Data lain yang berhasil dikumpulkan diantaranya yaitu, fitur yang tidak berfungsi pada menu pilihan pelayanan, serta sub submenu 
pada menu pelayanan, informasi publik, regulasi, ppid pembantu dan galeri. terdapat 7 (tujuh) pilihan menu yang ditampilkan, dimana terdapat 6 (enam) menu yang berfungsi dan 1 (satu) tidak berfungsi, terdapat 26 (dua puluh enam) sub menu yang berfungsi semuanya dan terdapat 16 (enam belas) sub sub menu dimana hanya 1 (satu) yang berfungsi, dan sisanya yaitu 15 (lima belas) sub sub menu tidak berfungsi.

Peneliti juga mencari informasi mengenai keberadaan ruang kantor sekretariat PPID dan ruang Pengelolaan Pelayanan Informasi dan Dokumentasi KBB, namun tidak didapatkan data mengenai keberadaannya.

Dari penjelasan dimaksud, penulis tertarik untuk melakukan penelitian mengenai Difusi Kebijakan Keterbukaan Informasi Publik (KIP) di Kabupaten Bandung Barat yang memiliki beberapa indikasi masalah (diolah berdasarkan hasil observasi pra penelitian) sebagai berikut :

1. Penerapan kebijakan Keterbukaan Informasi Publik di Kabupaten Bandung Barat yang tidak diselenggarakan secara berkelanjutan;

2. Badan Pejabat Pengelola Informasi dan Dokumentasi (PPID) Kabupaten Bandung Barat tidak beroperasi;

3. Tidak tersedia Pelayanan Pengelolaan Informasi dan Dokumentasi oleh PPID KBB.

Mengacu pada pemaparan di atas, dalam penerapan kebijakan Keterbukaan Informasi Publik di Kabupaten Bandung Barat terdapat celah (gap) antara aspek yuridis formal (regulasi) dengan aspek empiris (realita), dimana secara faktual penerapan kebijakan KIP di Kabupaten Bandung Barat terlaksana tapi tidak berkelanjutan, tidak beroperasinya PPID KBB serta Pengelolaan Pelayanan Informasi dan Dokumentasi yang tidak tersedia. Maka, dapat dipertimbangkan bahwa terdapat kekeliruan atas mekanisme difusi kebijakan KIP yang dilakukan oleh Pemerintah Kabupaten Bandung Barat.

Atas pertimbangan dimaksud, penulis merumuskan sebuah pernyataan masalah yaitu, "Penerapan Kebijakan Keterbukaan Informasi Publik (KIP) di Kabupaten Bandung Barat yang tidak terlaksana secara berkelanjutan”. Dari pernyataan masalah tersebut, maka penulis merumuskan pertanyaan penelitian sebagai berikut : "Bagaimana Mekanisme Difusi Kebijakan Keterbukaan Informasi Publik (KIP) yang dilakukan oleh Pemerintah Kabupaten Bandung Barat?”

\section{Tujuan penelitian}

Penelitian akan dilakukan sebagai upaya mencapai tujuan yaitu untuk mengetahui bagaimana Mekanisme Difusi Kebijakan Keterbukaan Informasi Publik (KIP) yang dilakukan oleh Pemerintah Kabupaten Bandung Barat.

\section{Manfaat penelitian}

Penulis berharap bahwa hasil penelitian ini secara praktis dapat menjadi masukan bagi Pemerintah Daerah Kabupaten Bandung Barat terkait Mekanisme Difusi Kebijakan Keterbukaan Informasi Publik, dan secara akademis, peneliti berharap bahwa penelitian ini dapat memberi kontribusi penting sebagai referensi dalam penelitian yang berkaitan dengan tema Difusi Kebijakan Publik.

\section{TINJAUAN PUSTAKA}

Studi mengenai difusi kebijakan telah banyak dilakukan melalui berbagai kajian dalam bentuk karya ilmiah jurnal, beberapa di antaranya yang dijadikan rujukan studi difusi kebijakan yaitu jurnal tentang teori difusi kebijakan dari (Baybeck et al., 2011; Braun \& Gilardi, 2006; Dobbin et al., 2007; Graham et al., 2013).

Penelitian terdahulu sebagai rujukan dalam mengkaji difusi kebijakan KIP di Pemerintah Daerah Kabupaten Bandung Barat, dimana penelitian ini akan berfokus pada sudut pandang kajian administrasi publik dengan tema kajian yang beragam.

Oleh karenanya peneliti menggunakan metode systematic mapping study (SMS) yang diadopsi dari studi yang dilakukan oleh (Petersen et al., 2017) untuk memudahkan penyusunan berdasar wilayah atau kategori tertentu. SMS adalah metode yang berfungsi membangun skema klasifikasi dan struktur dari minat bidang penelitian. Dengan demikian, dapat mengidentifikasi cakupan bidang penelitian terdahulu dan memperlihatkan posisi kategori serta nilai kebaruan penelitian yang dilakukan oleh penulis.

Penelusuran penelitian terdahulu dilakukan dengan mengidentifikasi beberapa 
artikel dan jurnal yang masih relevan dengan penelitian. Dengan cara dimaksud dapat diperoleh state of the art penelitian yang akan dilakukan. Untuk lebih jelas dapat dilihat pada tabel sebagai berikut :

Tabel 3.1

Pencarian Jurnal Penelitian Terdahulu Based on Systematic Mapping Study

\begin{tabular}{|c|c|c|c|c|}
\hline $\begin{array}{l}\text { Sumber } \\
\text { Database }\end{array}$ & $\begin{array}{c}\text { Kata } \\
\text { Kunci } \\
\text { Pencarian }\end{array}$ & Terdeteksi & $\begin{array}{l}\text { Yang } \\
\text { sesuai }\end{array}$ & $(\%)$ \\
\hline 1 & 2 & 3 & 4 & 5 \\
\hline $\begin{array}{l}\text { SAGE } \\
\text { Journal }\end{array}$ & $\begin{array}{l}\text { Policy } \\
\text { Diffusion }\end{array}$ & 49.491 & 7 & $13,2 \%$ \\
\hline JSTOR & $\begin{array}{l}\text { Policy } \\
\text { Diffusion }\end{array}$ & 110.723 & 5 & $9,4 \%$ \\
\hline $\begin{array}{l}\text { Research } \\
\text { Gate }\end{array}$ & $\begin{array}{l}\text { Policy } \\
\text { Diffusion }\end{array}$ & 32.784 & 29 & $54,7 \%$ \\
\hline $\begin{array}{l}\text { Science } \\
\text { Direct }\end{array}$ & $\begin{array}{l}\text { Policy } \\
\text { Diffusion }\end{array}$ & 78.725 & 2 & $3,7 \%$ \\
\hline $\begin{array}{l}\text { Semantic } \\
\text { Scholar }\end{array}$ & $\begin{array}{l}\text { Policy } \\
\text { Diffusion }\end{array}$ & 95.493 & 10 & $18,8 \%$ \\
\hline \multicolumn{3}{|c|}{ JUMLAH } & 53 & $100 \%$ \\
\hline
\end{tabular}

Kemudian pemetaan topik penelitian secara manual, dipilih yang terkait dengan tema penelitian, dengan susunan sebagai berikut :

Tabel 3.2

Pengklasifikasian Jurnal Penelitian Terdahulu Based on Systematic Mapping Study

\begin{tabular}{|c|c|c|c|}
\hline No. & Kategori & Sub Kategori & Studi \\
\hline & \multirow[t]{7}{*}{$\begin{array}{l}\text { Difusi } \\
\text { Kebijakan }\end{array}$} & $\begin{array}{l}\text { Teori / } \\
\text { Mekanisme } \\
\text { Difusi }\end{array}$ & $\begin{array}{l}\text { (Braun \& Gilardi, 2006; } \\
\text { Jahn et al., 2014; Meseguer, } \\
\text { 2005; Ring, 2014; Shipan \& } \\
\text { Volden, 2012) }\end{array}$ \\
\hline & & $\begin{array}{l}\text { Penelitian } \\
\text { Difusi }\end{array}$ & $\begin{array}{l}\text { (Adam, 2016; Hajaroh, } \\
\text { 2013; Karch et al., 2016; } \\
\text { Maggetti \& Gilardi, 2015; } \\
\text { Meydora, 2019; Rogers et } \\
\text { al., 1983; Starke, 2013) }\end{array}$ \\
\hline & & $\begin{array}{l}\text { Transfer } \\
\text { Kebijakan }\end{array}$ & $\begin{array}{l}\text { (Dolowitz \& Marsh, 2012; } \\
\text { Newmark, 2002) }\end{array}$ \\
\hline & & $\begin{array}{l}\text { Reformasi } \\
\text { Kepemimpinan }\end{array}$ & $\begin{array}{l}\text { (Lawrence et al., 2017; Zuin } \\
\text { et al., 2019) }\end{array}$ \\
\hline & & Inovasi & $\begin{array}{l}\text { (Karch et al., 2016; Owen } \\
\text { et al., 2006; Volden et al., } \\
\text { 2008) }\end{array}$ \\
\hline & & $\begin{array}{l}\text { Reformasi } \\
\text { Sosial }\end{array}$ & $\begin{array}{l}\text { (Bender et al., 2014; } \\
\text { McLendon \& Cohen- } \\
\text { Vogel, 2008; Meseguer, } \\
\text { 2005) }\end{array}$ \\
\hline & & $\begin{array}{l}\text { Kelompok } \\
\text { Kepentingan/ } \\
\text { Pergerseran } \\
\text { Konstelasi } \\
\text { Aktor }\end{array}$ & $\begin{array}{l}\text { Garrett \& Jansa, 2015; } \\
\text { Douglas \& Hartley,2015; } \\
\text { Kristin N \& M. Jansa. } \\
2015 .\end{array}$ \\
\hline
\end{tabular}

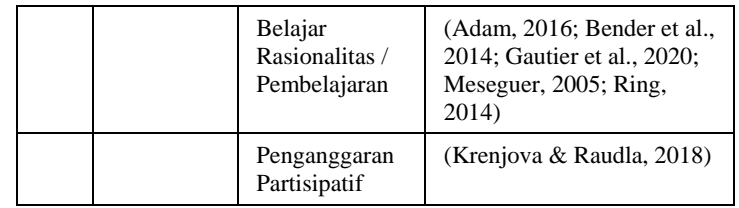

Sumber: Data diolah peneliti (2020) diadopsi dari (Petersen et al., 2017) Dari penyusunan yang dilakukan, peneliti menyatakan bahwa berdasarkan pemilihan lokus, judul riset "Difusi Kebijakan Keterbukaan Informasi Publik di Kabupaten Bandung Barat" merupakan topik penelitian yang memiliki nilai kebaruan, termasuk ke dalam kategori mekanisme difusi dan atau penelitian difusi.

\section{Difusi Kebijakan}

Penelitian ini akan menganalisis tentang Difusi Kebijakan Keterbukaan Informasi Publik di Kabupaten Bandung Barat. Maka akan diuraikan dan dijelaskan secara spesifik mengenai Difusi Kebijakan, kemudian memaparkan Kebijakan Keterbukaan Informasi Publik.

Difusi kebijakan secara garis besar dapat dipahami sebagai sebuah pilihan kebijakan oleh pemerintah (negara, provinsi, kota/kabupaten, dsb.) yang dipengaruhi berbagai implikasi dan dampak dari penerapan kebijakan yang telah dilaksanakan oleh suatu pemerintah di tempat yang lain. Disampaikan oleh (Graham et al., 2013) bahwa difusi kebijakan pada umumnya didefenisikan sebagai suatu suatu proses dimana pemerintahan membuat pilihan kebijakan yang dipengaruhi oleh pilihan kebijakan serupa yang ada pada pemerintah lainnya. Adapun (Karch et al., 2016) menuturkan penjelasannya bahwa difusi berkaitan dengan suatu gerakan / perpindahan sebuah kebijakan yang melintasi batas-batas yurisdiksi. Sedangkan menurut (Braun \& Gilardi, 2006), Difusi kebijakan didefinisikan sebagai sebuah proses dimana pilihan-pilihan kebijakan saling bergantung, dimana pilihan yang dibuat oleh seorang pengambil keputusan dipengaruhi oleh pilihan yang dibuat oleh para pengambil keputusan lain, dan sebaliknya. Sedangkan Difusi kebijakan menurut (Maggetti \& Gilardi, 2015) dalam (Bender et al., 2014) adalah proses dimana pilihan-pilihan kebijakan dalam satu unit yang dipengaruhi oleh pilihanpilihan kebijakan di unit lain.

Dari beberapa pengertian tersebut dapat dipahami bahwa difusi kebijakan pada intinya 
mencakup beberapa elemen yaitu proses (process), pilihan kebijakan (policy choices), dan pengambilan keputusan (decision-maker) sehingga inti dari Difusi kebijakan merupakan proses dimana pilihan kebijakan dalam satu unit dipengaruhi dengan pilihan kebijakan di unit lain.

Dalam memahami definisi-defenisi yang telah disampaikan, maka dalam konteks Difusi Kebijakan KIP di Kabupaten Bandung Barat, dapat diasumsikan sebagai cara yang dipilih dalam membuat kebijakan yang dipengaruhi dari keberhasilan penerapan kebijakan serupa di tempat lain, baik dari level yang sama ataupun berbeda, dalam yurisdiksi negara yang sama ataupun lintas negara.

Maggetti \& Gilardi (2013) dalam (Bender et al., 2014) berpendapat bahwa difusi kebijakan secara umum dipahami sebagai suatu hal yang berkenaan dengan sebaran kebijakan antara unit-unit kebijakan yang saling ketergantungan berdasarkan gambaran karaketeristiknya. Unit bisa jadi bermacammacam dengan memperhatikan tingkat (internasional, transnasional, nasional, subnasional, dan sebagainya) dan jenisnya (negara, kota, organisasi publik/negeri, perusahaan, dan sebagainya). Dolowitz \& Marsh (2000) dalam (Bender et al., 2014) menjelaskan bahwa dalam kaitan politis difusi kebijakan berarti "Suatu proses, dimana pengetahuan tentang kebijakan, pengaturan administrasi, institusi dan ide dalam satu sistem politik (dulu atau sekarang) digunakan dalam pengembangan kebijakan, pengaturan administratif, institusi dan ide dalam sistem politik lain” lebih lanjut dijelaskan bahwa pemahaman tentang difusi kebijakan tersebut dapat diketahui untuk membedakan antara pengertian difusi kebijakan dalam arti sempit dan dalam arti luas. Difusi kebijakan dalam arti sempit dipahami sebagai cara mengkordinasikan kebijakan yang ditandai dengan tidak adanya keterlibatan instansi Pemerintah Pusat.

\section{Mekanisme Difusi Kebijakan}

Dalam kajiannya Rogers dalam (Bender et al., 2014) menjelaskan bahwa difusi mengacu pada penyebaran gagasan dan konsep, informasi teknis dan praktik aktual dalam sistem sosial. Adapun komunikasi yang digunakan adalah jenis komunikasi khusus, karena pesannya yaitu agar menjadi peduli dengan ide baru. Inilah kebaruan dari gagasan pada isi pesan komunikasi yang menjadikan karakter istimewa difusi. Difusi merupakan sejenis perubahan sosial, yang didefinisikan sebagai proses perubahan yang terjadi dalam struktur dan fungsi sistem sosial. Ketika gagasan baru ditemukan, tersebar dalam suatu bentuk komunikasi khusus dan dipilih untuk diterapkan atau ditolak sehingga dapat menyebabkan konsekuensi tertentu berupa terjadinya perubahan sosial.

Rogers juga menjelaskan bahwa difusi adalah proses dimana sebuah inovasi dikomunikasikan melalui saluran-saluran tertentu dari waktu ke waktu diantara para anggota dalam sistem sosial melalui komunikasi yang bersifat khusus karena pesan yang akan dikomunikasikan berkaitan dengan gagasan baru.

Dari hasil pemikiran (Braun \& Gilardi, 2006), menjelaskan bahwa difusi diartikan sebagai proses dimana pilihan saling bergantung, yaitu pilihan suatu pemerintahan mempengaruhi pilihan yang dibuat oleh orang lain dan sebaliknya pilihan suatu pemerintahan dipengaruhi oleh pilihan yang dibuat. (Boushey, 2012) mengemukakan pemahamannya bahwa sebuah pengambilan kebijakan mendapatkan pengaruh dari suatu tekanan politik dan sosial, sehingga terbias pada perbedaan difusi inovasi kebijakan yang terjadi.

Meskipun beberapa studi telah menemukan banyak bukti bahwa kebijakan benar-benar menyebar, kurang lebih difusi kebijakan dipahami sebagai mekanisme spesifik yang menyebabkan sebuah kebijakan menyebar dari satu pemerintah ke pemerintah lainnya. Artinya, jika satu pemerintah menerapkan kebijakan itu karena pemerintah lain telah melakukannya, hal ini menjelaskan tindakan pemerintah tersebut sebagai sebuah difusi. Sehingga dari penjelasan tersebut dapat dipahami bahwa kebijakan menyebar dari suatu pemerintahan ke pemerintahan lainnya karena adanya hal atau peristiwa yang mempengaruhi disebut Difusi kebijakan.

Mengacu pada pemikiran (Shipan \& Volden, 2012), disampaikan bahwa para ahli telah mengidentifikasi empat mekanisme utama difusi kebijakan, yaitu: persaingan, pembelajaran, imitasi dan pemaksaan. Sama halnya dengan yang disampaikan dalam (Graham et al., 2013) bahwa karena terdapat 104 istilah yang secara mendasar berkenaan dengan 
difusi kebijakan, maka dengan demikian dapat direduksi menjadi, empat proses utama atau mekanisme difusi kebijakan. Mekanisme ini adalah pembelajaran, persaingan, paksaan, dan sosialisasi.

Sama dengan yang dijelaskan oleh (Maggetti \& Gilardi, 2015), bahwa difusi kebijakan dapat didefinisikan sebagai proses dimana pilihan kebijakan dalam satu unit dipengaruhi oleh pilihan kebijakan di unit lain (Braun dan Gilardi 2006; Simmons et al. 2006; Gilardi 2012; Graham et al. 2013). Definisi ini sangat luas dan didasarkan pada definisi yang lebih umum. Dalam literatur ini menyebut sebagai "mekanisme". Istilah yang lebih tepatnya bervariasi, tetapi mekanisme difusi dapat dikelompokkan ke dalam tiga kategori besar: pembelajaran, persaingan, dan persaingan, walaupun beberapa sarjana akan menambahkan mekanisme difusi kebijakan pemaksaan di dalamnya.

Dari pemaparan berbagai penjelasan atas hasil pemikiran tersebut, dapat dikatakan bahwa suatu pemerintahan melakukan difusi kebijakan melalui mekanisme pembelajaran, persaingan, peniruan atau pemaksaan untuk menentukan pilihan kebijakannya. Atau bisa dikatakan bahwa penerapan kebijakan Keterbukaan Informasi Publik di Kabupaten Bandung Barat merupakan manifestasi dari difusi kebijakan, yang terjadi melalui mekanisme pembelajaran, persaingan, peniruan atau pemaksaan.

Pada bagian ini akan dijelaskan lebih mendalam tentang empat mekanisme dalam teori difusi kebijakan, yaitu sebagai berikut:

\section{Pembelajaran (Learning)}

(Maggetti \& Gilardi, 2015) menyatakan bahwa pembelajaran didefinisikan sebagai proses dimana kebijakan dalam satu unit dipengaruhi oleh konsekuensi kebijakan serupa di unit lain. Dengan kata lain, adopsi kebijakan dalam satu unit lebih mungkin jika kebijakan tersebut berhasil di tempat lain (Meseguer 2004; Braun dan Gilardi 2006; Volden 2006; Gilardi 2010; Jensen dan Lindstädt 2012). Ada berbagai bentuk kesuksesan. Keberhasilan dapat dikaitkan dengan (a) tujuan yang dirancang untuk dicapai oleh kebijakan, (b) tantangan implementasinya dan / atau (c) dukungan politiknya.

\section{Persaingan (Competition)}

(Meseguer, 2005) berpendapat bahwa di dalam suatu kompetisi atau persaingan tersirat difusi kebijakan yang didorong oleh kekuatan pasar. Kemudian (Maggetti \& Gilardi, 2015) menyampaikan bahwa persaingan terjadi ketika unit bereaksi satu sama lain dalam upayauntuk menarik atau mempertahankan sumber daya atau potensi (pendapatan). Dan (Baybeck et al., 2011) juga menyatakan bahwa teori strategis difusi kita melalui persaingan lebih dapat diterapkan secara luas, karena banyak pilihan kebijakan yang dibuat oleh pemerintah (nasional, negara bagian dan lokal) mempengaruhi "pilihan lokasi” yang dibuat oleh orang atau perusahaan, yang pada gilirannya memiliki konsekuensi positif atau negatif bagi pemerintah.

\section{Peniruan (Imitation)}

Dalam tulisannya (Volden, 2017) menyampaikan "Terpisah dari pembelajaran, negara dapat mengadopsi kebijakan yang ditemukan di tempat lain melalui mekanisme difusi yang biasa disebut sebagai "imitasi". Imitasi melibatkan penyalinan kebijakan yang ditemukan di tempat lain tanpa memperhatikan keefektifannya. Secara umum, apa yang tercakup dalam peniruan adalah semacam aktivitas menggiring, di mana negara ragu-ragu untuk menjadi penggerak pertama, tetapi juga tidak ingin tertinggal dan tampak tidak sinkron dengan yang lain, terutama jika hal itu memberi kesan negatif pada pembuat kebijakan terpilih.

\section{Pemaksaan (Coercion)}

(Bender et al., 2014) menjelaskan pemaksaan terjadi ketika unit politik dipaksa untuk menerapkan kebijakan tertentu oleh aktor politik lain, misalnya negara bagian atau organisasi internasional atau supranasional. Syarat dapat dianggap sebagai salah satu bentuk pemaksaan. Pemaksaan adalah ukuran top-down dan hal itu bukan mekanisme pemerintahan / tata kelola horisontal yang sebagaimana ditekankan oleh definisi sempit difusi kebijakan. Sedangkan menurut (Gilardi \& Wasserfallen, 2018) bahwa organisasi-organisasi internasional dan negaranegara yang kuat dapat menekan negara-negara bagian menerapkan kebijakan-kebijakan tertentu. Mekanisme yang khas adalah persyaratan untuk mengakses sumber daya 
tertentu, pemerintah di level nasional harus mematuhi persyaratan kebijakan yang diberikan.

\section{Kerangka Pemikiran}

Difusi kebijakan Keterbukaan Informasi

Publik di Kabupaten Bandung Barat dalam penelitian ini digambarkan dengan menggunakan teori yang disampaikan oleh (Bender et al., 2014; Braun \& Gilardi, 2006; Dobbin et al., 2007; Graham et al., 2013; Maggetti \& Gilardi, 2015; Shipan \& Volden, 2012; Volden et al., 2008) bahwa difusi kebijakan di seluruh pemerintahan yang memfokuskan pada empat mekanisme, yaitu apakah ditempuh melalui mekanisme pembelajaran (learning), atau persaingan (competition), atau emulasi / peniruan (mimicry) atau pemaksaan (coercion). Dengan penjelasan berikut :

1. Pembelajaran (learning) terkait dengan upaya Pemerintah Daerah Kabupaten Bandung Barat dalam memusatkan perhatian pada kebijakan itu sendiri dengan memahami konsekuensi politik dan efektivitas penerapan kebijakan Keterbukaan Informasi Publik;

2. Persaingan (competition), bahwa Pemerintah Daerah Kabupaten Bandung Barat melakukan antisipasi atau bereaksi terhadap sikap pemerintah daerah lain dalam penerapan kebijakan Keterbukaan Informasi Publik untuk menarik perhatian atau pempertahankan sumber-sumber (potensi) perekonomian daerah;

3. Peniruan (imitation) yaitu Pemerintah Kabupaten Bandung Barat meniru penerapan kebijakan Keterbukaan Informasi Publik dari pemerintah daerah lain tanpa mempedulikan efek penerapan kebijakan tersebut;

4. Pemaksaan (coercion) dimana Kabupaten Bandung Barat turut serta dalam menerapkan kebijakan Keterbukaan Informasi Publik sebagai tuntutan dari pelaksanaan (UU-KIP, 2008).

\section{Proposisi}

Berdasarkan penelusuran awal yang telah dituangkan di dalam kerangka pemikiran, maka penulis mengemukakan proposisi sebagai berikut : "Pemerintah Daerah Kabupaten
Bandung Barat telah melaksanakan penerapan kebijakan Keterbukaan Informasi Publik melalui mekanisme pembelajaran, persaingan, peniruan dan pemaksaan”.

\section{METODE PENELITIAN}

Penelitian dilakukan secara sistematis dan ilmiah, artikel penelitian akan disusun dengan klasifikasi atau jenis penelitian deskriptif kualitatif, pendekatan kualitatif dipilih dengan tujuan untuk menggambarkan pandangan dan persepsi agar mampu mengungkapkan difusi kebijakan Keterbukaan Informasi Publik di Kabupaten Bandung Barat secara mendalam dan menyeluruh. Maka hasil akhir penelitan diharapkan dapat memberikan saran atau rekomendasi tentang difusi kebijakan yang tepat dalam penerapan kebijakan Keterbukaan Informasi Publik di Kabupaten Bandung Barat.

\section{Teknik Pengumpulan Data}

Data-data penelitian yang akan dimuat dan digunakan dalam penelitian ini berupa data penelitian deskriptif, yang akan dikumpulkan oleh peneliti melalui :

1. Studi kepustakaan, dengan mempelajari berbagai referensi literasi karya ilmiah.

2. Studi lapangan, dengan melakukan pengamatan langsung terhadap objek penelitian guna mengetahui permasalahan yang terjadi melalui beberapa cara yaitu:

\section{a. Wawancara}

Wawancara dilakukan dengan tujuan untuk mengumpulkan data melalui kegiatan tanya jawab langsung dengan pihak-pihak terkait.

\section{b. Obeservasi}

Obeservasi atau pengamatan yaitu teknik pengumpulan data lapangan dengan berperan sebagai pengamat terhadap objek penelitian.

\section{c. Dokumen}

Dokumen-dokumen yang digunakan dalam penelitian untuk melakukan pengumpulan data.

\section{Informan}

Dengan teknik purposive yang merupakan teknik pengambilan sumber data dengan pertimbangan tertentu. Teknik ini menekankan asumsi penguasaan informasi dari informan tentang hal yang akan dipertanyakan terhadapnya berkaitan dengan kebijakan Keterbukaan Informasi Publik di Kabupaten 
Bandung Barat yang didasarkan pada beberapa pertimbangan sebagai berikut :

1. Kewenangan / Otoritas Informan

2. Pengetahuan dan Wawasan

3. Kapasitas Formal

\section{Triangulasi Data}

Peneliti menggunakan teknik triangulasi untuk menguji keabsahan data dalam penelitian ini. Mengacu pada pemikiran yang disampaikan oleh (Creswell, 2014), bahwa teknik triangulasi akan menggunakan berbagai sumber data informasi dengan memeriksa bukti dari sumber dan menggunakannya untuk membangun justifikasi yang koheren untuk tema, dimana akan diterapkan dua dari tiga jenis triangulasi yang telah disebutkan sebelumnya, yang akan dijelaskan sebagai berikut :

\section{Triangulasi Sumber Data}

Triangulasi sumber data dapat dilakukan dengan membandingkan data dari berbagai sumber yang berbeda Ritchie \& Lewis (2003).

2. Triangulasi Teknik

Peneliti melakukan triangulasi teknik pengumpulan data dengan cara mencari informasi pada sumber yang sama tetapi dengan teknik yang berbeda.

\section{Teknik Analisis Data}

Peneliti menggunakan teknik analisis data mengacu pada Model Interaktif hasil pemikiran (Miles \& Huberman, 1994), diantaranya terdiri dari :

1. Data Reduction, yang diartikan sebagai kegiatan merangkum, memilah hal-hal pokok menjadi suatu bentuk analisis penajaman, penggolongan, pengarahan, pengurangan yang tidak diperlukan dan mengorganisir data sehingga dapat memverifikasi kesimpulan akhirnya.

2. Data Display. Setelah data direduksi maka langkah selanjutnya yaitu penyajian data. Yaitu menyajikan sekumpulan informasi yang tersusun dengan memberi muatan kemungkinan untuk dilakukan penarikan kesimpulan dan pengambilan tindakan.

3. Conclusion Drawing or Verification. Langkah selanjutnya yaitu penarikan kesimpulan dan verifikasi. Karena kesimpulan awal yang dikemukakan peneliti masih bersifat premature, sehingga ketika peneliti melakukan penelusuran ke lapangan, peneliti bisa menemukan bukti- bukti valid yang menambah atau mengurangi daya dukung kesimpulan awal.

Kesimpulan dalam penelitian kualitatif adalah berupa temuan tambahan yang sebelumnya belum hadir. Peneliti akan mengidentifikasi suatu difusi kebijakan keterbukaan informasi publik di Kabupaten Bandung Barat berdasarkan teori dari (Bender et al., 2014; Braun \& Gilardi, 2006; Dobbin et al., 2007; Graham et al., 2013; Maggetti \& Gilardi, 2015; Shipan \& Volden, 2012; Volden et al., 2008).

\section{HASIL DAN PEMBAHASAN}

\section{Keterbukaan Informasi Publik}

Pemerintah Republik Indonesia berupaya menyesuaikan berbagai perkembangan pola hidup secara global untuk dapat bertahan dari berbagai tekanan, terutama perkembangan teknologi yang menuntun pada peradaban baru dalam kegiatan penyebaran informasi. Sadar akan hal tersebut maka untuk mengupayakan pengelolaan segala jenis informasi untuk dijadikan tolak ukur pelayanan yang prima, maka dibentuklah suatu regulasi dalam bentuk UU No. 14 Tahun 2008 tentang Keterbukaan Informasi Publik.

Regulasi ini dihadirkan kepada setiap badan publik, yaitu semua lembaga dari level nasional sampai daerah, untuk terlibat dalam memberikan akses layanan informasi publik bagi masyarakat. Regulasi ini dihadirkan tentunya ingin mewujudkan suatu cita-cita dalam penyelenggaraan pemerintahan yang baik, dengan mendasarkan pada pertimbangan bahwa informasi merupakan hak asasi manusia untuk pengembangan diri, dan meningkatkan kesejahteraan.

Rambu-rambu yang ingin dipertegas dalam penyajian regulasi (UU-KIP, 2008) ini berupa kategori informasi yang merupakan esensi dari rangkuman terhadap kebutuhan informasi publik itu sendiri. Dengan demikian batasan terhadap pemahaman dari bentukbentuk informasi diharapkan selaras, tidak saling merugikan dan dapat menjamin kondusifitas lingkungan sosial dimana kebijakan itu diterapkan. Kategori dimaksud yaitu pembagian bentuk informasi yaitu, 1).informasi yang secara berkala wajib disediakan dan diumumkan; 2).informasi yang secara serta merta wajib 
diumumkan; 3).informasi yang wajib tersedia setiap saat; dan 4).informasi-informasi dalam kategori dikecualikan.

\section{Analisa Difusi Kebijakan KIP di Kabupaten Bandung Barat}

Dari hasil penelitian yang dilakukan, maka peneliti akan memaparkan analisa dari berbagai data yang telah dikumpulkan, yang diantaranya berupa data primer yang didapatkan melalui studi lapangan dengan cara observasi, dokumentasi dan wawancara kepada beberapa informan, kemudian juga terdapat data sekunder yang dihasilkan melalui studi pustaka dengan cara mencari referensi atas dokumen regulasi, kajian serta dokumen pelaksanaan kegiatan mengenai kebijakan KIP di Kabupaten Bandung Barat.

Sebagaimana disampaikan oleh (Graham et al., 2013) bahwa difusi kebijakan pada umumnya didefinisikan sebagai sikap pemerintahan yang membuat pilihan kebijakan berdasarkan kebijakan serupa yang ada pada pemerintah lainnya. Hal tersebut dalam konteks penelitian ini terkait dengan tema penerpana kebijakan KIP di Kabupaten Bandung Barat sebagai bentuk difusi kebijakan KIP berdasarkan (UU-KIP, 2008) tentang Keterbukaan Informasi Publik, yang mana telah banyak diterapkan oleh beberapa daerah dan badan publik dengan berbagai hasil tertentu.

Disampaikan juga oleh (Braun \& Gilardi, 2006; Gilardi et al., 2020; Shipan \& Volden, 2006; Simmons et al., 2006) bahwa studi difusi dibagi menjadi empat mekanisme utama, yaitu pembelajaran dimana pembuat kebijakan berfokus dalam memperhatikan konsekuensi kebijakan di tempat yang lain, lalu persaingan yaitu fokus pembuat kebijakan dalam menyesuaikan kebijakan dengan unit lain untuk tujuan ekonomi, lalu peniruan yaitu fokus pada penyalinan suatu kebijakan, dan paksaan yaitu bentuk penekanan untuk merubah pilihan kebijakan dari pihak yang lebih superior, selanjutnya analisis akan dipaparkan berdasarkan kriteria dimaksud.

\section{Pembelajaran (Learning)}

Mekanisme kebijakan pembelajaran (learning) menjelaskan bahwa terdapat suatu pembelajaran dari keberhasilan penerapan kebijakan di tempat lain atau mempelajari kebijakan dari berbagai literatur ilmiah (Volden et al., 2008). Dari penjelasan tersebut dapat dipahami bahwa pembelajaran merujuk pada kebijakan yang telah sukses di tempat lain. Selain itu, pembelajaran juga bisa dilakukan melalui suatu literatur ilmiah, penelitian atau jurnal dan yang sejenisnya.

Dari pemahaman tersebut, maka pembelajaran dalam penerapan kebijakan KIP di Kabupaten Bandung Barat pada umumnya mengacu pada aturan perundangan yang berlaku, yaitu (UU-KIP, 2008) tenang Keterbukaan Informasi Publik. Dinamika perkembangan kebijakan KIP di Kabupaten Bandung Barat juga tidak terlepas dari berbagai literatur ilmiah, dimana terdapat suatu kajian terkait pengembangan Komisi Informasi Daerah. Difusi kebijakan KIP melalui mekanisme pembelajaran diartikan sebagai suatu upaya mendapatkan suatu referensi, data, informasi, masukan dalam rangka mempersiapkan penerapan kebijakan serupa, sehingga penerapan kebijakan KIP dapat dilaksanakan dengan suatu pola yang menjadi acuan dimana pola atau pedoman tersebut dibangun atas dasar masukan dari hasil pembelajaran yang dilakukan di tempat lain yang telah lebih dahulu melaksanakannya dan telah berhasil.

Atas dasar data yang dikumpulkan, maka ditampilkan sebagai berikut :

$$
\text { Tabel } 4.3
$$

Data hasil wawancara mekanisme pembelajaran dalam difusi kebijakan publik

\begin{tabular}{|l|l|}
\hline \multicolumn{1}{|c|}{$\begin{array}{c}\text { Sumber } \\
\text { Informasi }\end{array}$} & \multicolumn{1}{|c|}{ Hasil Reduksi Data } \\
\hline Informan 1 & $\begin{array}{l}\text { Melakukan segala upaya dalam } \\
\text { mempelajari keberhasilan } \\
\text { penerapan kebijakan KIP di } \\
\text { tempat lain untuk kemudian } \\
\text { diadopsi dan disesuaikan agar } \\
\text { dapat dilaksanakan sesuai } \\
\text { kemampuan yang ada di } \\
\text { Kabupaten Bandung Barat. }\end{array}$ \\
\hline Informan 4 & $\begin{array}{l}\text { Tujuan studi yang dilaksanakan } \\
\text { adalah untuk mengadopsi sistem } \\
\text { atau pola kerja keberhasilan } \\
\text { penerapan kebijakan KIP dari } \\
\text { tempat lain untuk dapat } \\
\text { diimplementasikan di Kabupaten } \\
\text { Bandung Barat. }\end{array}$ \\
\hline Informan 5 & $\begin{array}{l}\text { Dalam merumuskan regulasi } \\
\text { dibutuhkan suatu kajian yang } \\
\text { didasari oleh pemikiran dan hasil } \\
\text { pembelajaran atas keberhasilan } \\
\text { pelaksanaan di tempat lain, } \\
\text { terutama dalam tata kelola }\end{array}$ \\
\hline
\end{tabular}




\begin{tabular}{|c|c|}
\hline & \begin{tabular}{lcr} 
layanan & informasi & dan \\
dokumentasi & publik & \multicolumn{2}{c}{ sebagai } \\
masukan dalam & persiapan \\
penerapan kebijakan & KIP di \\
Kabupaten Bandung Barat.
\end{tabular} \\
\hline Informan 6 & $\begin{array}{l}\text { Pembelajaran dan pendalaman } \\
\text { terhadap sistem atau pola kerja } \\
\text { PPID di tempat lain yang berhasil } \\
\text { dalam penerapan kebijakan KIP. } \\
\text { Perlu juga memperhatikan } \\
\text { jaminan atas kelancaran } \\
\text { distribusi data dan informasi } \\
\text { yang dilakukan oleh petugas dari } \\
\text { setiap perangkat daerah dalam } \\
\text { menunjang keberhasilan } \\
\text { penerapan kebijakan KIP di } \\
\text { Kabupaten Bandung Barat. }\end{array}$ \\
\hline
\end{tabular}

Sumber : Diolah oleh Penulis (2020)

Dari data yang ditampilkan dapat ditarik kesimpulan awal bahwa Pemerintah Kabupaten Bandung Barat melakukan penerapan kebijakan Keterbukaan Informasi Publik atas dasar mekanisme pembelajaran dalam difusi kebijakan. Hal tersebut dibuktikan dengan pelaksanaan benchmarking dan studi mengenai penerapan kebijakan keterbukaan informasi publik pada Pemerintah Provinsi Jawa Barat, Komisi Informasi Provinsi Jawa Barat, Kabupaten Banyuwangi, dan NTB serta Kota Cirebon.

\section{Persaingan (Competition)}

Mekanisme difusi kebijakan persaingan menurut (Dobbin et al., 2007; dan Simmons et al., 2006) dijelaskan sebagai strategi yang diterapkan untuk mendapatkan perhatian sehingga mampu menghidupkan aktifitas perekonomian, sedangkan (Gilardi \& Wasserfallen, 2018) menyampaikan bahwa persaingan didefinisikan sebagai proses dimana para pembuat kebijakan melakukan antisipasi atau bereaksi terhadap sikap pemerintah atau negara lain untuk menarik perhatian atau pempertahankan sumber-sumber perekonomian. (Bender et al., 2014) juga menjelaskan bahwa mekanisme persaingan dalam difusi kebijakan akan tergantung pada area kebijakan, yaitu antara proses dan produk peraturan dimana persaingan dapat menyebabkan peraturan untuk menekan biaya proses untuk meningkatkan daya saing perekonomian, atau dalam kondisi sebaliknya dimana terdapat upaya meningkatkan biaya penerapan kebijakan untuk meningkatkan persaingan.

Atas dasar data yang dikumpulkan, maka ditampilkan sebagai berikut :

Tabel 4.5

Data hasil wawancara mekanisme persaingan dalam difusi kebijakan publik

\begin{tabular}{|c|c|}
\hline $\begin{array}{c}\text { Sumber } \\
\text { Informasi } \\
\end{array}$ & Hasil Reduksi Data \\
\hline Informan 1 & $\begin{array}{l}\text { Tidak berjalannya PPID secara } \\
\text { berkelanjutan menyebabkan } \\
\text { Kabupaten Bandung Barat ada di } \\
\text { peringkat terbawah di kawasan } \\
\text { Bandung Raya dalam hal } \\
\text { ketersediaan informasi dan } \\
\text { dokumentasi publik, hal yang } \\
\text { tidak seharusnya terjadi karena } \\
\text { peran penanggungjawab PPID } \\
\text { sudah melekat pada instansi } \\
\text { dalam nomenklatur yang baru. }\end{array}$ \\
\hline Informan 3 & $\begin{array}{l}\text { Menganggap bahwa salah satu } \\
\text { yang menyebabkan } \\
\text { penyelenggaraan PPID tidak } \\
\text { dilakukan secara berkelanjutan } \\
\text { adalah tidak jelasnya pihak atau } \\
\text { instansi yang harus } \\
\text { bertanggungjawab dalam } \\
\text { menyelenggarakan PPID. }\end{array}$ \\
\hline Informan 5 & $\begin{array}{l}\text { Kendala yang dihadapi dalam } \\
\text { penyelenggaraan PPID adalah } \\
\text { prosedur birokrasi yang tidak } \\
\text { efisien, yang kemudian memicu } \\
\text { resistensi dari setiap perangkat } \\
\text { daerah terutama dalam menjamin } \\
\text { distribusi data dan informasi } \\
\text { pada PPID. }\end{array}$ \\
\hline
\end{tabular}

Sumber : Diolah oleh Penulis (2020)

Dari data yang ditampilkan dapat ditarik kesimpulan awal bahwa Pemerintah Kabupaten Bandung Barat menitikberatkan pada pencarian sebuah masalah yang menyebabkan penyelenggaraan PPID menjadi tidak berkelanjutan, sehingga dalam pemeringkatan ketersediaan informasi dan dokumentasi publik di Kabupaten Bandung Barat lebih rendah daripada daerah lainnya.

Selain itu, diperlukan upaya dalam meningkatkan peran serta dari setiap pihak yang terlibat dalam penyelenggaraan PPID, termasuk perangkat daerah yang harus menjamin ketersediaan data dan distribusinya, serta peran aktif dari Pejabat pengarah dalam memberikan penegasan atas pendelegasian kewenangan instansi yang berkewajiban menyelenggarakan 
layanan informasi dan dokumentasi publik melalui PPID Kabupaten Bandung Barat. Dengan begitu Pemerintah Kabupaten Bandung Barat dapat menjamin ketersediaan informasi dan dokumentasi publik sesuai dengan norma dan ketentuan yang berlaku.

\section{Peniruan (Imitation)}

Suatu pengertian difusi kebijakan dengan metode peniruan adalah kegiatan yang dilakukan oleh pengambil kebijakan dalam mengadopsi suatu kebijakan, dimana akan selalu berhubungan dengan cara memfokuskan pada bagaimana agar suatu kebijakan yang dilakukan dapat terlihat sama dengan penerapan kebijakan serupa yang telah berhasil dilaksanakan oleh pemerintah di daerah lainnya (Shipan \& Volden, 2012). Dengan kata lain, metoda difusi kebijakan peniruan ini adalah bentuk penyalinan suatu penerapan kebijakan yang telah berhasil diterapkan di tempat yang lain, dengan harapan agar bisa memberikan hasil yang sama.

(Volden, 2017) juga menyampaikan bahwa peniruan berkaitan dengan penyalinan kebijakan yang ditemukan di tempat lain tanpa memperhatikan efektifitasnya, kegiatan peniruan merupakan penggiringan yang dapat dilakukan yang ditujukan kepada pihak-pihak (sebagai pengambil keputusan / penentu kebijakan) yang memiliki keraguan dalam menentukan langkah, namun di sisi lain mereka merasa tidak ingin tertinggal dan tidak ingin terlihat tidak dapat beradaptasi dengan suatu tren tertentu, sehingga dapat menimbulkan kesan negatif dari lingkungan sosialnya.

Tabel 4.6

Data hasil wawancara mekanisme peniruan dalam difusi kebijakan publik

\begin{tabular}{|c|c|}
\hline $\begin{array}{l}\text { Sumber } \\
\text { Informasi }\end{array}$ & Hasil Reduksi Data \\
\hline Informan 4 & $\begin{array}{lr}\text { Untuk menunjang pelaksanaan } \\
\text { penerapan kebijakan KIP di } \\
\text { Kabupaten Bandung Barat, } \\
\text { diperlukan } & \text { dukungan } \\
\text { sumberdaya terutama dalam hal } \\
\text { pemanfaatan } \\
\text { informasi. }\end{array}$ \\
\hline Informan 6 & $\begin{array}{l}\text { Tujuan dilakukan studi tentang } \\
\text { penyelenggaraan PPID di tempat } \\
\text { lain adalah untuk meniru sistem } \\
\text { dan pola kerja yang dijalankan. }\end{array}$ \\
\hline Informan 7 & \begin{tabular}{lcr} 
Salah & satu & \multicolumn{2}{c}{ penunjang } \\
penyelenggaraan & PPID adalah
\end{tabular} \\
\hline
\end{tabular}

\begin{tabular}{|l|l|}
\hline infrastruktur berupa alat atau \\
aplikasi yang dikembangkan \\
dengan cara meniru penggunaan \\
aplikasi dari Kementerian \\
Kominfo dan Pemerintah Kota \\
Bandung yang telah berhasil \\
menyelenggarakan PPID dalam \\
melayani ketersediaan informasi \\
dan dokumentasi publik.
\end{tabular}

Sumber : Diolah oleh Penulis (2020)

Dapat dipahami bahwa pemanfaatan teknologi informasi dalam penyelenggaraan PPID di Kabupaten Bandung Barat merupakan suatu aktifitas peniruan dari penerapan kebijakan yang sama di tempat lain.

Beberapa penjelasan yang didapat dari hasil wawancara yang dilakukan, dapat ditarik kesimpulan awal bahwa difusi kebijakan KIP di Bandung Barat, dipengaruhi oleh berbagai penilaian terhadap suatu keberhasilan yang telah dilaksanakan di tempat yang lain, yang terjadi secara lintas organisasi, dimana terdapat suatu pengaruh kuat berupa penerjemahan suatu ketentuan secara vertikal, yaitu penerjemahan aturan atau regulasi yang diterbitkan oleh pusat, sehingga menjadi suatu pedoman dalam pengelolaan PPID di Bandung Barat. Serta terdapat juga pengaruh yang terjadi secara horisontal, dimana terdapat pengaruh pemanfaatan suatu ilmu dan teknologi dari keberhasilan penerapan kebijakan KIP dan keberhasilan pengelolaan PPID pemerintah daerah lainnya, yang dijadikan sebagai benchmark bagi penerapan kebijakan KIP dan pengelolaan PPID di Kabupaten Bandung Barat.

\section{Pemaksaan (Coercion)}

Berdasarkan penjelasan dari (Simmons et al., 2006), pemaksaan merupakan suatu kegiatan yang mengupayakan penggunaan segala jenis kekuatan yang dimiliki oleh para penentu kebijakan atau pengambil keputusan yang lebih kuat untuk menekan penentu kebijakan yang lebih lemah untuk mengubah perilaku atau kebijakan yang dipilihnya. Secara teori, metode pemaksaan dapat dilakukan secara langsung ataupun melalui perantara yang sangat mungkin melibatkan suatu ancaman dan bahkan penggunaan kekuatan fisik, manipulasi biaya dan keuntungan ekonomi atau bahkan monopoli informasi dengan tujuan mempengaruhi 
perubahan atau penerapan kebijakan di tempat lain.

Atas penelusuran yang telah dilakukan, ditampilkan data sebagai berikut :

Tabel 4.7

Data hasil wawancara mekanisme pemaksaan dalam difusi kebijakan publik

\begin{tabular}{|c|l|}
\hline \multicolumn{1}{|c|}{$\begin{array}{c}\text { Sumber } \\
\text { Informasi }\end{array}$} & \multicolumn{1}{|c|}{ Hasil Reduksi Data } \\
\hline Informan 1 & $\begin{array}{l}\text { Sepakat untuk menyampaikan } \\
\text { informasi dan dokumentasi } \\
\text { publik secara konsisten serta } \\
\text { berkelanjutan, dengan } \\
\text { pembatasan yang normatif } \\
\text { berdasarkan amanat dalam (UU- } \\
\text { KIP, 2008). }\end{array}$ \\
\hline Informan 4 & $\begin{array}{l}\text { Yang menjadi dasar penerapan } \\
\text { kebijakan keterbukaan informasi } \\
\text { publik di Kabupaten Bandung } \\
\text { Barat, yaitu karena amanat } \\
\text { dalam (UU-KIP, 2008) yang } \\
\text { mengharuskan bahwa informasi } \\
\text { publik wajib disediakan dan } \\
\text { disampaikan kepada masyarakat }\end{array}$ \\
& $\begin{array}{l}\text { Informasi publik harus dapat } \\
\text { disampaikan kepada masyarakat, } \\
\text { namun juga tetap } \\
\text { memperhatikan norma atau kode } \\
\text { Informan 6 penyampaian informasi } \\
\text { etik publik dari Pemerintah Daerah } \\
\text { Kabupaten Bandung Barat } \\
\text { kepada masyarakat. Namun } \\
\text { tidak semua informasi publik } \\
\text { dapat menjadi konsumsi publik. }\end{array}$ \\
\hline
\end{tabular}

Sumber : Diolah oleh Penulis (2020)

(UU-KIP, 2008) tentu akan menjadi pedoman bagi badan publik dalam melaksanakan penerapan keterbukaan dan ketersediaan informasi dan dokumentasi publik, regulasi yang bersifat top-down merupakan mekanisme pemaksaan dalam teori difusi kebijakan publik yang terjadi di Kabupaten Bandung Barat.

\section{SIMPULAN}

Atas dasar hasil analisis yang telah dilakukan, maka disampaikan simpulan yang berkenaan dengan difusi kebijakan KIP di Kabupaten Bandung Barat yaitu sebagai berikut:

Penulis menyampaikan simpulan penelitian mengenai bagaimana difusi kebijakan Keterbukaan Informasi Publik di Kabupaten Bandung Barat sebagai berikut :
1. Penerapan Kebijakan KIP di Kabupaten Bandung Barat merupakan suatu difusi kebijakan yang bersifat memaksa (coercion) atas dasar pembentukan Undang-Undang No. 14 Tahun 2008 tentang Keterbukaan Informasi Publik dari Pemerintah Pusat yang harus dilakukan oleh setiap badan publik, termasuk Pemerintahan Daerah Kabupaten Bandung Barat;

2. Mekanisme difusi kebijakan KIP di Kabupaten Bandung Barat yang berkaitan dengan peniruan dilakukan dalam hal pemanfaatan teknologi sistem informasi atau aplikasi PPID, peniruan tidak mencakup mengenai tata cara pemeliharaan ataupun pengembangan aplikasi PPID, peniruan terhadap perumusan kebijakan juga dilakukan dengan menjadikan (UUKIP, 2008) sebagai dasar dan pedoman penyusunan (Kepbup-PPID, 2017; PerbupPPID, 2018);

3. Pemerintah Kabupaten Bandung Barat belum memperhatikan mekanisme difusi kebijakan KIP yang memandang persaingan antar Pemerintah Daerah sebagai faktor keberhasilan penerapan kebijakan KIP secara berkelanjutan, sehingga walaupun berada pada posisi paling rendah seBandung Raya, namun tidak ada respon yang signifikan. Persaingan merupakan hal yang dapat dibuat atau dikondisikan dalam rangka mendapatkan dukungan kuat dari masyarakat, karena tingkat kepercayaan masyarakat kepada Pemerintah Kabupaten Bandung Barat akan mampu menjadi stimulus dan motivasi positif dalam mewujudkan penerapan Kebijakan KIP yang berkelanjutan;

4. Mekanisme pembelajaran dalam difusi kebijakan KIP dilakukan dengan mempelajari, pengamatan dan studi melalui benchmarking terhadap daerah lain yang telah mampu menyelenggarakan penerapan kebijakan KIP dengan penyelenggaraan PPID yang berkesinambungan dan berkelanjutan. Namun begitu tidak melakukan tata kelola yang proporsional terhadap PPID itu sendiri. Upaya penyelenggaraan kebijakan KIP tidak mendapatkan dukungan yang kuat dari para pemangku jabatan yang memiliki kewenangan yang tinggi. Sehingga dukungan dari setiap perangkat daerah 
(OPD) yang menjadi bagian dari PPID itu sendiri menjadi lemah dan tidak menganggap penerapan kebijakan KIP melalui penyelenggaraan PPID bukan sebagai prioritas utama. Dampaknya adalah lemahnya dukungan sumberdaya terhadap penyelenggaraan PPID, yaitu sumberdaya anggaran yang akan menopang penyediaan sumberdaya lainnya, seperti biaya honorarium sumberdaya manusia, sarana prasarana, biaya penunjang operasional dan biaya lainnya;

5. Penerapan difusi kebijakan dilakukan melalui mekanisme pemaksaan (coercif), peniruan (imitation) dan pembelajaran (learning). Namun tidak memperhatikan mekanisme difusi kebijakan persaingan (competition), meskipun penekanan lebih banyak terdapat pada mekanisme difusi pembelajaran (learning) namun mekanisme persaingan juga memiliki pengaruh dan dampak pada upaya penerapan kebijakan KIP melalui PPID secara berkelanjutan.

\section{Saran}

Berdasarkan hasil penelitian yang merekomendasikan beberapa saran, baik secara akademis maupun secara praktis yaitu sebagai berikut :

\section{Saran Akademis}

1. Kajian mengenai difusi kebijakan Keterbukaan Informasi Publik perlu dilakukan secara lebih menyeluruh, komprehensifitas suatu kajian akan mampu menunjang pelaksanaan suatu kegiatan secara praktis, sehingga mampu juga memberikan berbagai informasi mengenai kendala-kendala yang akan mungkin muncul dan dengan begitu mampu disusun berbagai upaya dalam mengatasinya sedini mungkin.

2. Hadirnya teori difusi kebijakan yang masih terbilang jarang dan belum banyak digunakan dalam berbagai kajian di Indonesia, oleh karenanya untuk mendapatkan hasil yang lebih komprehensif dalam penyusunan suatu kebijakan publik, maka dapat dipertimbangkan untuk menggali suatu fenomena ataupun menyusun suatu kajian dalam sektor pemerintahan yang mengacu pada pemanfaatan teori difusi kebijakan.
3. Penentuan sebuah benchmarking atau barometer dalam menyusun kajian dalam rangka menyusun kebijakan KIP jangan dibatasi oleh cakupan pemerintahan secara lokal di Indonesia, namun bisa juga melihat dalam tatanan lingkungan internasional seperti penerapan kebijakan KIP di negara lain dalam sektor formal pemerintahan ataupun sektor privat (profesional swasta) yang lebih maju dan telah berhasil menerapkannya.

\section{Saran Praktis}

1. Bagi pemerintah Kabupaten Bandung Barat, perlu dilakukan sinkronisasi terhadap pemahaman atas kebijakan Keterbukaan Informasi Publik, hal ini penting dilakukan dan disampaikan oleh para pemangku kepentingan di tingkat Legislatif, Eksekutif maupun Birokrat sehingga memiliki kesepakatan baik secara politis maupun secara profesional. Dengan terbentuknya suatu kesepakatan atas definisi keterbukaan informasi publik yang tepat, maka tidak akan ada pihak yang merasakan terbebani atau merasakan tidak nyaman karena seolah tidak ada sekat penutup atau seolah merasa seperti ditelanjangi. Begitupun dengan pihak lain yang dapat memiliki akses terhadap informasi sesuai dengan kapasitas dan kebutuhannya berdasarkan prosedur yang berlaku.

2. Penguatan kordinasi antara berbagai OPD yang dapat dikomando oleh pimpinan SKPD yaitu Pejabat Sekretaris Daerah yang juga sekaligus berperan sebagai Kepala PPID utama akan sangat krusial, terutama dalam membangun kemudahan dan peran aktif para kepala OPD yang berada di bawah kordinasinya. Sehingga tidak terdapat kordinasi yang terputus di PPID.

3. Upaya peningkatan kesadaran akan pentingnya informasi pada akhirnya akan mampu menjadi pertimbangan atas pentingnya upaya peningkatan kualitas penyampaian informasi dalam penerapan kebijakan KIP yang memerlukan berbagai dukungan atas sumberdaya, sarana prasarana dan fasilitas yang memadai. Hal ini diperlukan dalam rangka memberi dukungan kepada penyelenggara PPID sebagai pengelola layanan informasi dan 
dokumentasi publik pada Pemerintah Kabupaten Bandung Barat.

4. Semangat penerapan kebijakan KIP di Kabupaten Bandung Barat harus memperhatikan dasar penyusunan kebijakan yang tepat, melakukan pembelajaran, penumbuhan persaingan, peniruan atau adopsi dan pemaksaan harus dilakukan secara ideal, disesuaikan seperlunya dengan kondisi di lingkungan lokal, serta tetap memperhatikan analisa dampak dan konsekuensi secara politis di masyarakat.

5. Pemilihan kebijakan di Kabupaten Bandung Barat juga dapat mempertimbangkan pemanfaatan mekanisme dari teori difusi kebijakan yang mampu memberikan analisa komprehensif, hal ini diperlukan dalam upaya menjaga keberlanjutan dari penerapan kebijakan yang dipilih, khususnya kebijakan KIP.

6. Memperkuat hubungan yang saling bersinergi antara pemerintahan dan masyarakat melalui penerapan kebijakan KIP yang berorientasi pada peningkatan peranan masing-masing, dimana pemerintah berperan sebagai agen pelaksana kegiatan pembangunan dan masyarakat yang memiliki peran sebagai kontrol sosial atas penyelenggaraan pemerintahan. Hal ini akan mampu menumbuhkan positivisme dan mewujudkan kondusifitas dalam lingkungan sosial masyarakat di Kabupaten Bandung Barat, sehingga pemerintah bisa mendapatkan kemudahan dukungan masyarakat atas segala program dan kegiatan yang dilakukan.

\section{DAFTAR PUSTAKA}

\section{Buku}

Abdul Wahab, Solichin. (2017). Analisis Kebijakan. Dari Formulasi ke Penyusunan Model-Model Implementasi Kebijakan Publik. PT. Bumi Aksara. Jakarta

Agustino, Leo. (2020). Dasar-Dasar Kebijakan Publik. CV. Alvabeta. Bandung

Creswell, J. W. (2014). Qualitative, Quantitative, and Mixed Methods
Approaches. Research Design. In Sage

Journal (Vol.

https://doi.org/10.1017/CBO978110741

5324.004

Mardiasmo. (2002). Otonomi dan Manajemen Keuangan Daerah. Penerbit ANDI. Yogyakarta

Miles, M. B., \& Huberman, A. M. (1994). Qualitative Data Analysis: An Expanded Sourcebook. In Sage Publications.

Nugroho, Riant. (2018). Public Policy. Dinamika Kebijakan Publik, Analisis Kebijakan Publik, Manajemen Politik Kebijakan Publik, Etika Kebijakan Publik. PT. Elex Media Komputindo. Jakarta

Purwanto, Erwan Agus. (2015). Implementasi Kebijakan Publik. Konsep dan Aplikasinya di Indonesia. Gava Media. Yogyakarta

Rogers, E. M., Singhal, A., \& Quinlan, M. M. (1983). Diffusion of innovations. In An Integrated Approach to Communication Theory and Research, Third Edition. https://doi.org/10.4324/9780203710753 $-35$

Rogers, Everett M. (1995). Diffusion of Innovations - Edisi Ketiga. Free Press. New York.

Sinambela, Lijan Poltak. (2020). Reformasi Pelayanan Publik. Teori, Kebijakan dan Implementasi. PT. Bumi Aksara. Jakarta

Winarno, Budi. (2014). Kebijakan Publik. Teori, Proses dan Studi Kasus. CAPS. Yogyakarta.

\section{Jurnal}

Adam, C. (2016). Simulating policy diffusion through learning: Reducing the risk of false positive conclusions. Journal of Theoretical Politics, 28(3), 497-519. https://doi.org/10.1177/095162981558146 1

Baybeck, B., Berry, W. D., \& Siegel, D. A. (2011). A strategic theory of policy diffusion via intergovernmental 
competition. Journal of Politics, 73(1), 232-247.

https://doi.org/10.1017/S00223816100009 88

Bender, K., Keller, S., \& Willing, H. (2014). The Role of International Policy Transfer and Diffusion for Policy Change in Social Protection - A Review of the State of the Art. IZNE Social Protection Working Paper. International Policy Learning and Policy Change: Scientific Inputs for the Dialogue on Social Protection with Global Partners, 14(1), 1-33. https://doi.org/10.18418/978-3-96043017-9

Braun, D., \& Gilardi, F. (2006). Taking "Galton's problem" seriously: Towards a theory of policy diffusion. Journal of Theoretical Politics, 18(3), 298-322. https://doi.org/10.1177/095162980606435 1

Creswell, J. W. (2014). Qualitative, Quantitative, and Mixed Methods Approaches. Research Design. In Sage Journal (Vol. 4). https://doi.org/10.1017/CBO97811074153 24.004

Dobbin, F., Simmons, B., \& Garrett, G. (2007). The Global Diffusion of Public Policies: Social Construction, Coercion, Competition, or Learning? Annual Review of Sociology, 33(1), 449-472. https://doi.org/10.1146/annurev.soc.33.09 0106.142507

Dolowitz, D. P., \& Marsh, D. (2012). The Future of Policy Transfer Research. Political Studies Review, 10(3), 339-345. https://doi.org/10.1111/j.14789302.2012.00274.x

Gautier, L., De Allegri, M., \& Ridde, V. (2020). Transnational Networks' Contribution to Health Policy Diffusion: A Mixed Method Study of the Performance-Based Financing Community of Practice in Africa. International Journal of Health Policy and Management, $\quad 0(\mathrm{x}), \quad 1-14$. https://doi.org/10.34172/ijhpm.2020.57
Gilardi, F. (2015). The Diffusion of Policy Perceptions: Evidence from a Structural Topic Model *. September, 1-34. http://www.fabriziogilardi.org/resources/t alks/2015-06-26-Smoking-bans-EPSAhandout.bmr.pdf

Gilardi, F., Füglister, K., \& Luyet, S. (2009). Learning from others: The diffusion of hospital financing reforms in OECD countries. Comparative Political Studies, 42(4), 549-573. https://doi.org/10.1177/001041400832742 8

Gilardi, F., Shipan, C. R., \& Wueest, B. (2020). Policy Diffusion: The Issue-Definition Stage *. 1-65.

Gilardi, F., \& Wasserfallen, F. (2018). The politics of policy diffusion. European Journal of Political Research, 58(4), 1245-1256. https://doi.org/10.1111/14756765.12326

Graham, E., Shipan, C., \& Volden, C. (2013). The Diffusion of Policy Diffusion Research. British Journal of Political Science, 43(3), 673-701.

Hajaroh, M. (2013). Difusi Kebijakan Pengarusutamaan Gender Pada Individu: Refleksi Terhadap Metode Penelitian Difusi. Jurnal Penelitian Dan Evaluasi Pendidikan, 15(2), 342-368. https://doi.org/10.21831/pep.v15i2.1101

Jahn, D., Kuitto, K., Düpont, N., \& Stephan, S. (2014). Uneven responsiveness to diffusion effects? Regional patterns of unemployment policy diffusion in Western and Eastern Europe CWED Working Paper Series. November.

Karch, A., Sean, C., \& Woods, N. D. (2016). How looking only at policy diffusion " successes " between states may be misleading. 1-4.

Kepbup-PPID. (2017). Kepbup Bandung Barat No 800 Tahun 2017 tentang Penetapan Struktur Organisasi Pejabat Pengelola Informasi dan Dokumentasi Pemerintah 
Kabupaten Bandung Barat (p. 10).

Krenjova, J., \& Raudla, R. (2018). Policy Diffusion at the Local Level: Participatory Budgeting in Estonia. Urban Affairs Review, 54(2), 419-447. https://doi.org/10.1177/107808741668896 1

Lan, P. T. T. (2013). THE DIFFUSION OF NORMS, RULES AND MECHANISMS FOR THE ENFORCEMENT OF LABOR STANDARDS AND THE RESOLUTION OF DISPUTES IN THE ASIA- PACIFIC, IN PARTICULAR AMONG SIGNATORY COUNTRIES OF THE TPP. Victorie University of Wellington, 26(4), 1-37.

Lawrence, E., Bohmelt, T., Lehrer, R., Fagerholm, A., Laver, M., Meijers, M. J., Rauh, C., \& Prosser, C. (2017). Exploring the Effects of Party Policy Diffusion on Parties 'Election Strategies. Acta Politica, 35(144), 88-101. https://doi.org/10.1057/s41269-018-00806

Maggetti, M., \& Gilardi, F. (2015). Problems (and solutions) in the measurement of policy diffusion mechanisms. Journal of Public Policy, 36(1), 87-107. https://doi.org/10.1017/S0143814X14000 $35 \mathrm{X}$

McLendon, M. K., \& Cohen-Vogel, L. (2008). Understanding education policy change in the American states: Lessons from political science. Handbook of Education Politics and Policy, 30-51.

Meseguer, C. (2005). Policy learning, policy diffusion, and the making of a new order. Annals of the American Academy of Political and Social Science, 598(March), 67-82.

https://doi.org/10.1177/000271620427237 2

Meydora, E. Y. (2019). Proses Difusi Inovasi EAgribusiness : Regopantes Pada End-User Komoditas Pertanian Di Jabodetabek. Commed : Jurnal Komunikasi Dan Media,
3(2),

133.

https://doi.org/10.33884/commed.v3i2.98 2

Newmark, A. J. (2002). An integrated approach to policy transer and diffusion. Review of Policy Research, 19(2), 151-178. https://doi.org/10.1111/j.15411338.2002.tb00269.x

Owen, N., Glanz, K., Sallis, J. F., \& Kelder, S. H. (2006). Evidence-Based Approaches to Dissemination and Diffusion of Physical Activity Interventions. American Journal of Preventive Medicine, 31(4 SUPPL.), 35-44.

https://doi.org/10.1016/j.amepre.2006.06. 008

Perbup-PPID. (2018). Perbup KBB No. 20 Tahun 2018 tentang Pengelolaan Pelayanan Informasi dan Dokumentasi di Lingkungan Pemerintahan Daerah. 3(32), 1-44.

Petersen, K., Feldt, R., Mujtaba, S., \& Mattson, M. (2017). Systematic Mapping Studies in Software Engineering. Software Engineering, 58(6), 484-489. https://doi.org/10.1016/j.pedneo.2016.08.0 11

Ring, J. J. (2014). The diffusion of norms in the international system. ProQuest Dissertations and Theses, 243. https://proxy.bc.edu/login?qurl=https\%3A \%2F\%2Fsearch.proquest.com\%2Fdocvie w\%2F1618206614\%3Faccountid\%3D967 3\%0Ahttp://bc-

primo.hosted.exlibrisgroup.com/openurl/B CL/services_page?url_ver=Z39.882004\&rft_val_fmt=info:ofi/fmt:kev:mtx:d issertation\&genre $=$ disser

Rogers, E. M., Singhal, A., \& Quinlan, M. M. (1983). Diffusion of innovations. In An Integrated Approach to Communication Theory and Research, Third Edition. https://doi.org/10.4324/978020371075335

Shipan, C. R., \& Volden, C. (2006). Bottom-up federalism: The diffusion of antismoking 
policies from U.S. cities to states. American Journal of Political Science, 50(4), 825-843. https://doi.org/10.1111/j.1540-

5907.2006.00218.x

Shipan, C. R., \& Volden, C. (2012). Policy diffusion: Seven lessons for scholars and practitioners. Public Administration Review, 72(6), 788-796. https://doi.org/10.1111/j.15406210.2012.02610.x

Simmons, B. A., Dobbin, F., \& Garrett, G. (2006). Introduction: The international diffusion of liberalism. International Organization, 60(4), 781-810. https://doi.org/10.1017/S00208183060602 67

Starke, P. (2013). Qualitative methods for the study of policy diffusion: Challenges and available solutions. Policy Studies Journal, 41(4), 561-582. https://doi.org/10.1111/psj.12032

UU-KIP. (2008). UU RI No 14 Tahun 2008 Tentang Keterbukaan Informasi Publik. In UU RI No 14 Tahun 2008 Tentang Keterbukaan Informasi Publik: Vol. I.

Volden, C. (2017). Policy diffusion in polarized times: The case of the affordable care act. Journal of Health Politics, Policy and Law, 42(2), 363-375. https://doi.org/10.1215/036168783766762

Volden, C., Ting, M. M., \& Carpenter, D. P. (2008). A formal model of learning and policy diffusion. American Political Science Review, 102(3), 319-332. https://doi.org/10.1017/S00030554080802 71

Zuin, V., Delaire, C., Peletz, R., Cock-Esteb, A., Khush, R., \& Albert, J. (2019). Policy Diffusion in the Rural Sanitation Sector: Lessons from Community-Led Total Sanitation (CLTS). World Development, 124, 104643. https://doi.org/10.1016/j.worlddev.2019.1 04643 